\title{
Anatomical and Physical Properties of Indonesian Bamboos Carbonized at Different Temperatures ${ }^{1}$
}

\author{
Se-Hwi Park ${ }^{2}$ - Jae-Hyuk Jang ${ }^{3}$ - Nyoman J Wistara ${ }^{2}$ - Wahyu Hidayat ${ }^{4}$. \\ Min Lee $\mathbb{D}^{3, \dagger} \cdot$ Fauzi Febrianto $\mathbb{D}^{2, \dagger}$
}

\begin{abstract}
Tropical bamboo species, which have a very rapid growth rate, are considered as a promising non-timber forest product capable of exhibiting new functionality by carbonization technology. This study was conducted to compare the characteristics of carbonized bamboos from Andong (G. pseuudoarundinacea (Steudel) Widjaja), Hitam (G. atrovialacea), Tali (G. apus), Kuning (B. vulgaris Var. striata (Lodd. Ex Lindl)), and Ampel (B. vulgaris Scharad. ex Wendland), and Betung (D. asper). Each bamboo was carbonized at 200, 400, 600, 800, and 1,000 ${ }^{\circ} \mathrm{C}$, respectively, and their physical and anatomical characteristics were investigated. The result showed that the volume and weight of carbonized bamboo decreased with increasing carbonization temperature and showed the substantial changes of volume and weight between 200 and $400{ }^{\circ} \mathrm{C}$. The highest and the lowest density of carbonized samples were found in Ampel bamboo and Betung bamboo, respectively. The density of all carbonized bamboos tended to decrease after carbonization at 200 and $400{ }^{\circ} \mathrm{C}$ and relatively become constant afterwards. The carbonized bamboo prepared at 800 and $1,000{ }^{\circ} \mathrm{C}$ showed better refining degree. The results of the anatomical observation showed that the vascular diameter of carbonized bamboo decreased with increasing carbonization temperature, and the shrinkage in radial and tangential direction showed similar tendency. Statistical analysis showed that there was significant correlation between physical contraction and anatomical contraction. Based on the results of this study, comprehensive data about Indonesian bamboo charcoals could be obtained and it will be useful for future application studies.
\end{abstract}

Keywords: Indonesian bamboo, carbonization, carbonized bamboo, pyrolysis, regression analysis

\section{INTRODUCTION}

In the world, the distribution area of bamboo is about 37 million hectares (ha) (Lobovikov et al., 2007). About 11 genera and 35 bamboo species are growing in
Indonesia, and total amount of Indonesian bamboo forest occupies $5 \%$ of bamboo forest in the world (approx. 2.2 million ha, INBAR 2005). In Indonesia, bamboo has been cultivated with trees and edible crops in some of the residential gardens called "Pekarangan"

\footnotetext{
${ }^{1}$ Date Received July 18, 2018, Date Accepted October 8, 2018

2 Department of Forest Products, Faculty of Forestry, Bogor Agricultural University, IPB Dramaga Campus, Bogor, 16680, Indonesia

${ }^{3}$ National Institute of Forest Science, Seoul 02455, Republic of Korea

${ }^{4}$ Department of Forestry, Faculty of Agriculture, University of Lampung, Bandar Lampung 35141, Indonesia

$\dagger$ Corresponding author: Min Lee (e-mail: mlee81@korea.kr, ORCID: 0000-0002-0497-9362)

$\dagger$ Corresponding author: Fauzi Febrianto (e-mail: febrianto76@yahoo.com, ORCID: 0000-0002-0964-2179)
} 
and is widely distributed in Java, Bali, and Sulawesi areas. Bamboo is one of the BBC (Bamboo, Banana, Coconut) group which has played a very important role in daily life in Indonesia. It has been used for architecture, household goods, furniture, musical instruments, textiles, and mats after first simple physical processing (Febrianto et al., 2014; Yudodibroto, 1985). Moreover, bamboo has been used as materials of paper and plywood after secondary processing (Sutardi et al., 2015). Bamboo resources have been exported to Australia and Europe beyond domestic consumption, reaching up to 3 million US dollars in 2007 year (Hardiani and Dewy, 2014).

However, the use of bamboo has been steadily declining due to the appearance of alternatives, such as plastics, for wood-based products. In addition, Indonesian bamboo exports have fallen to less than half of 2007 year (1.5 million US \$). Nevertheless, the Indonesian government still considered bamboo as a potential non-timber product, and aimed to change the crisis of bamboo industry by transition of bamboo to competitive resources. Under the specific goal of encouraging use of bamboo in daily life, the development of bamboo industry was proceeding in Central Java, West Java, East Java, Bali, etc. (Hardiani and Dewy, 2014). It has been recognized that the high value added process on bamboo, which can guarantee the income of farm, is one of the important key to build bamboo industry which can encourage local people to participate, and a lot of research has been done. Maulana et al. (2017) and Febrianto et al. (2015, 2012) developed a durable bamboo oriented strand board (OSB) using Andong, Betung, and Ampel bamboo, and Kim et al. (2001) evaluated the characteristics of Tali bamboo by making bamboo zephyr. Jang et al. (2013) conducted a study to isolate nanocelluloses from Betung bamboo by the delignification method and apply them as reinforcing fillers for biodegradable polymers.
In particular, converting bamboo into biomass energy is the most prevalent field of applied research on bamboo utilization. Compared to coal, biomass generally does not require long production times and cause less environmental pollution (Basu, 2013). In addition, the rapid growth of bamboo could potentially replace depleting woody resources, so research has been actively pursued in line with current trends in green and renewable energy. Bamboo biomass produced by pyrolysis and carbonization has been used mainly as fuel for household and iron smelting in the past (Nurhayati, 1990). In recent years, carbonized bamboo has been used as a soil remediation agent (fertilizer papers) using a rich inorganic component of bamboo, or as a heavy metal adsorbent that improves the adsorption performance by developing microstructure (Mizuta et al., 2004; Wang et al., 2010). However, the bamboo industry in Indonesia is still staying in simple product compared with other advanced countries in research and development on bamboo biomass.

In this study, bamboo carbonization technology was applied to search the developing direction for bamboo industry in Indonesia. The genera of Bambusa, Gigantochola and Dendrocalamus have been widely used in Indonesia according to rapid growth rate and sympodial growing pattern. These were selected in this study and these bamboos were carbonized at different temperature. The anatomical and physical characteristics were investigated.

\section{MATERIALS and METHODS}

\subsection{Materials}

Six species of bamboo (4-5 years old) belong to Gigantocloa, Bambusa and Dendrocalamus genera were collected from experimental bamboo plantation of Bogor Agricultural University, in West Java, Indonesia. The secondary node from the ground of the sampled 
Se-Hwi Park $\cdot$ Jae-Hyuk Jang $\cdot$ Nyoman $\mathrm{J}$ Wistara $\cdot$ Wahyu Hidayat $\cdot$ Min Lee $\cdot$ Fauzi Febrianto

Table 1. Six Bamboos from West Java, Indonesia

\begin{tabular}{clcccc}
\hline $\begin{array}{c}\text { Common } \\
\text { name }\end{array}$ & \multicolumn{1}{c}{ Scientific name } & $\begin{array}{c}\text { Diameter* } \\
\mathbf{( c m )}\end{array}$ & $\begin{array}{c}\text { Thickness } \\
(\mathbf{m m})\end{array}$ & $\begin{array}{c}\text { Density } \\
\left(\mathbf{g} / \mathbf{c m}^{3}\right)\end{array}$ & $\begin{array}{c}\text { M.C. } \\
\mathbf{( \% )}\end{array}$ \\
\hline Andong & Gigantocloa pseudoarundinacea (Steudel) Widjaja & 12.1 & 12.56 & 0.71 & 8.4 \\
Hitam & Gigantocloa atroviolacea & 8.3 & 10.87 & 0.71 & 7.8 \\
Tali & Gigantocloa apus & 8.1 & 9.73 & 0.60 & 7.3 \\
Kuning & Bambusa vulgaris var. striata (Lodd. Ex Lindl.) & 7.9 & 17.37 & 0.67 & 7.6 \\
Ampel & Bambusa vulgaris Scharad. ex Wendland & 7.0 & 13.34 & 0.77 & 10.2 \\
Betung & Dendrocalamus asper & 14.0 & 22.43 & 0.56 & 7.1 \\
\hline
\end{tabular}

*Diameter of second node

bamboo was air-dried in ambient condition for 3 months and used in the experiment. Detailed information is given in Table 1.

\subsection{Carbonization}

One node of bamboo sample was cut at intervals of $25 \mathrm{~mm}$ in radial direction, and then cut at $40 \mathrm{~mm}$ intervals in the direction of the fiber. Cut samples (25 $\mathrm{mm}(\mathrm{R}) \times 40 \mathrm{~mm}(\mathrm{~L}))$ were carbonized at 200, 400, 600, 800 and $1,000{ }^{\circ} \mathrm{C}$. Carbonization was carried out according to the technique of producing charcoal using heat-resistant container (Park et al., 2009). It was possible to produce defect-free charcoal without additional injection of nitrogen. To prevent oxidation during the carbonization process, a dozen or more samples were alternately wrapped in newspaper and aluminum foil, and then placed in a small rectangular heat-resistant container with a lid. A heat-resistant container was placed in a laboratory electrical furnace (TST BT-F724, Korea) and carbonization was carried out at a target temperature by setting a heating rate at $50{ }^{\circ} \mathrm{C} / \mathrm{h}$. After reaching the target temperature of electrical furnace, it was maintained for 2 hours, and after natural cooling for sevral hours the heat-resistant container was taken out of the electric furnace and then the carbonized bamboo was taken.

\subsection{Evaluation of anatomical properties}

Sample preparation was conducted according to the method described by Kwon and Kim (2006). The cross section of the original bamboo specimen was prepared with a microtome after softening in water 2 weeks. After the carbonization, the specimens were machined to $5 \mathrm{~mm}(\mathrm{R}) \times 5 \mathrm{~mm}(\mathrm{~T})$ and the central part was broken to obtain a clean and parallel cutted surface. These specimens were coated with gold and palladium and observed with a scanning electron microscope (COXEM-30, COXEM, Korea). The anatomical characteristics of carbonized bamboo were analyzed mainly by array observation of the parenchyma cell and measuring the diameter of the lumen and vessel.

\subsection{Evaluation of physical properties}

\subsubsection{Moisture contents, weight and volume reduction rate, and density}

The physical characteristics of specimens were determined according to KS F 2198 (KSA, 2016) and KS F 2199 (KSA, 2016). The dimension and weight of control specimens and carbonized specimens were measured, and then all samples were dried at $103 \pm$ $2{ }^{\circ} \mathrm{C}$ for 24 hours. After cooling of samples at desiccator, dimension and weight of samples were measured again. 
Anatomical and Physical Properties of Indonesian Bamboos Carbonized at Different Temperatures

Table 2. Formulas for Physical Properties in This Study

\begin{tabular}{cclc}
\hline Number & \multicolumn{1}{c}{ Formula } & \multicolumn{1}{c}{ Explanation } & \multicolumn{1}{c}{ Standard } \\
\hline (1) & Moisture contents $(\%)=\frac{W_{n}-W_{o}}{W_{o}} \times 100$ & $W_{n}$ : Weight of air-dried sample & KS F 2199 \\
& & $W_{o}$ : Weight of oven-dried sample & \\
(2) & Volume reduction rate $(\%)=\left(V_{i}-\frac{V_{o}}{V_{i}}\right) \times 100$ & $V_{i}$ : Volume of initial sample \\
& & $V_{o}$ : Volume of oven-dried sample & KS F 2198 \\
(3) & Weight reduction rate $(\%)=\left(W_{i}-\frac{W_{o}}{W_{i}}\right) \times 100$ & $\begin{array}{l}W_{i}: \text { Weight of initial sample } \\
W_{o} \text { : Weight of oven-dried sample }\end{array}$ & KS F 2198 \\
& Density $(\%)=\frac{W}{V}$ & W: Weight of sample & KS F 2198 \\
\hline
\end{tabular}

The moisture contents, volume reduction rate, weight reduction rate, and density of samples were calculated by following formulas in Table 2 .

\subsubsection{Hardness}

The hardness of samples was measured by using Miura hardness tester (Miura, Japan). The special metal strips, which adjusted to 20 levels from lead to iron, were used in this experiment. The surface of control and carbonized specimens was scratched by metal strips for determining hardness (Hyodo and Fujii, 2016).

\subsubsection{Refining degree}

Refining is an operation that removes volatile gases at final stage of charcoal process, and is an important process for increasing the quality of charcoal by uniformizing carbonization degree of entire charcoal. The refining degree meter (Miura, Japan) designed by Dr. Kishimoto is device for measuring the electrical resistance index of surface on charcoal. The values of refining degree on charcoal produced at low temperature $\left(400{ }^{\circ} \mathrm{C}\right)$ and that on charcoal produced at high temperature $\left(1,000{ }^{\circ} \mathrm{C}\right)$ were indicated to $9.0\left(10^{9} \Omega\right)$ and $0\left(10^{\circ} \Omega\right)$, respectively (Park et al., 1998). The charcoal showing refining degree of 1 or less was considered to be in state of good carbonization and low in impurities (Kwon et al., 2011).

\subsection{Statistical analysis}

ANOVA and Duncan test (IBM SPSS ver. 21, IBM, USA) were used for the statistical analysis of physical and anatomical characteristics according to species and carbonization temperature.

\section{RESULTS and DISCUSSION}

\subsection{Anatomical characteristics}

The cross-sectional area of the bamboo was divided into peripheral zone, transitional zone, central zone, and inner zone according to the arrangement of the vascular system and applied to this study (Grosser $e t$ al., 1971). The peripheral zone was excluded from observation due to difficulty in identification by getting damage during carbonization. Anatomical observations of three preserved zone were performed according to the methods presented by Jeon et al. (2018). The representative figures of three zone were selected from partial samples and were shown in Fig. 1.

First of all, the shape of the vascular bundle was not clear in the transitional zone. The size was small and frequency of observation was high. The vascular bundle was wrapped around sclerenchyma sheath. Vascular bundle, sclerenchyma sheath, fiber bundle were fused, and these were distinguished gradually 


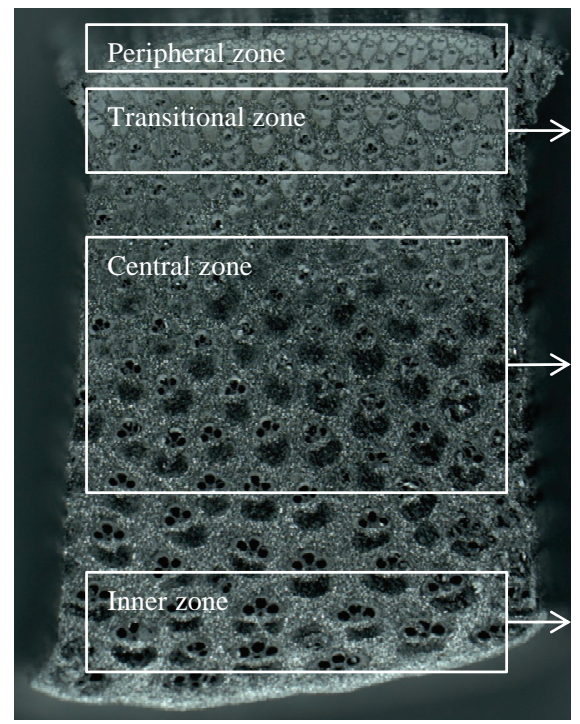

a. Classification (ex. Betung bamboo)
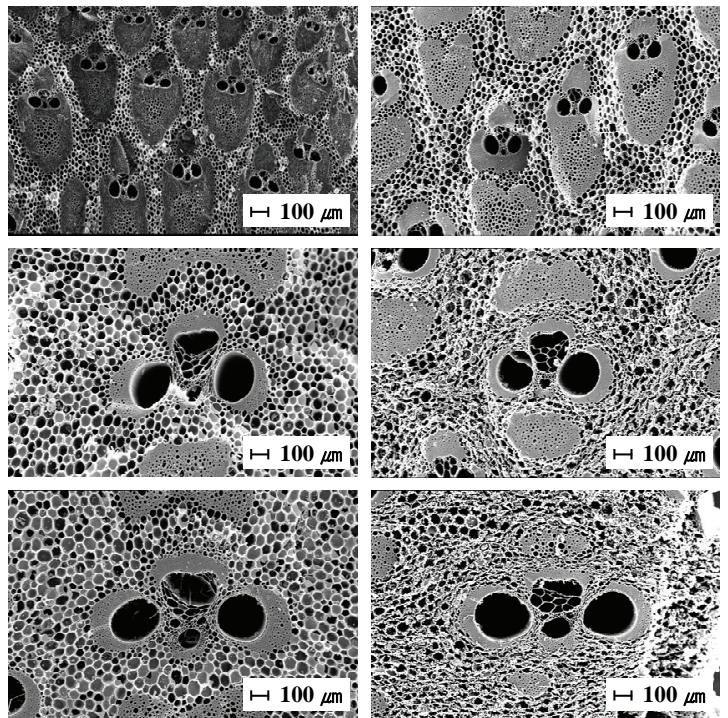

b. Carbonized Betung

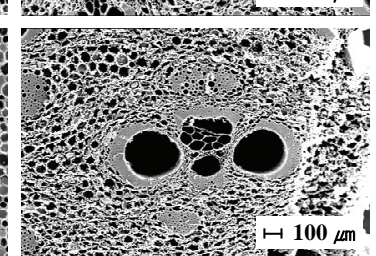

c. Carbonized Ampel

Fig. 1. The SEM images of Betung and Ampel bamboo samples carbonized at $600{ }^{\circ} \mathrm{C}$ according to the classification of observation area.

toward the central zone. In central zone, clear forms of vascular bundle consist of xylem, two large vessels, primitive phloem were observed. The sizes of vascular bundle were increased and the appearance frequency of that reduced compared to transitional zone. Clearly distinguished fiber bundles were located on inside or outside of vascular bundle. In inner zone, finally, inner zone was area adjacent to cavity space of bamboo culm, and consist of few flat vascular bundles which spread in radial direction. Occasionally, vascular bundle displayed a tangential direction. Fiber bundle was reduced or degraded. Kim et al. (2001) reported that same anatomical characteristics were observed in other Indonesian bamboos.

The SEM images taken by bamboo type and carbonization temperatures are shown in Fig. 2. Grosser et al. (1971) classified the types of bamboo vascular bundle into four types. Type I consists of only the vascular center of the vascular system, and type II consists of the vascular center of the vascular system in which the rear wall cells adjacent to the protoxylem are expanded. Type III is composed of one fiber located in the center of the tube and in the inner direction. Type IV takes the form of fiber in the outer direction in the form of type III. As a result of morphological identification, Andong bamboo was mainly observed as type III, rarely type IV. The remaining 5 species were type IV. It is consistent with the pattern of vascular bundle on Gigantochola, Bambusa, and Dendrocalamus genera (Liese, 1987).

To determine the change in cell size with carbonization temperature, we selected the largest pore size and clear type of vessel. The results of measuring the diameter of the vessel in the radial and tangential directions, according to the area classification displayed in Fig. 1, were shown in Fig. 3, Fig. 4, and Fig. 5, respectively. Since there was no significant difference between vessel diameter in radial direction and vessel diameter in tangential direction, only the value of radial direction was mentioned. 
Anatomical and Physical Properties of Indonesian Bamboos Carbonized at Different Temperatures
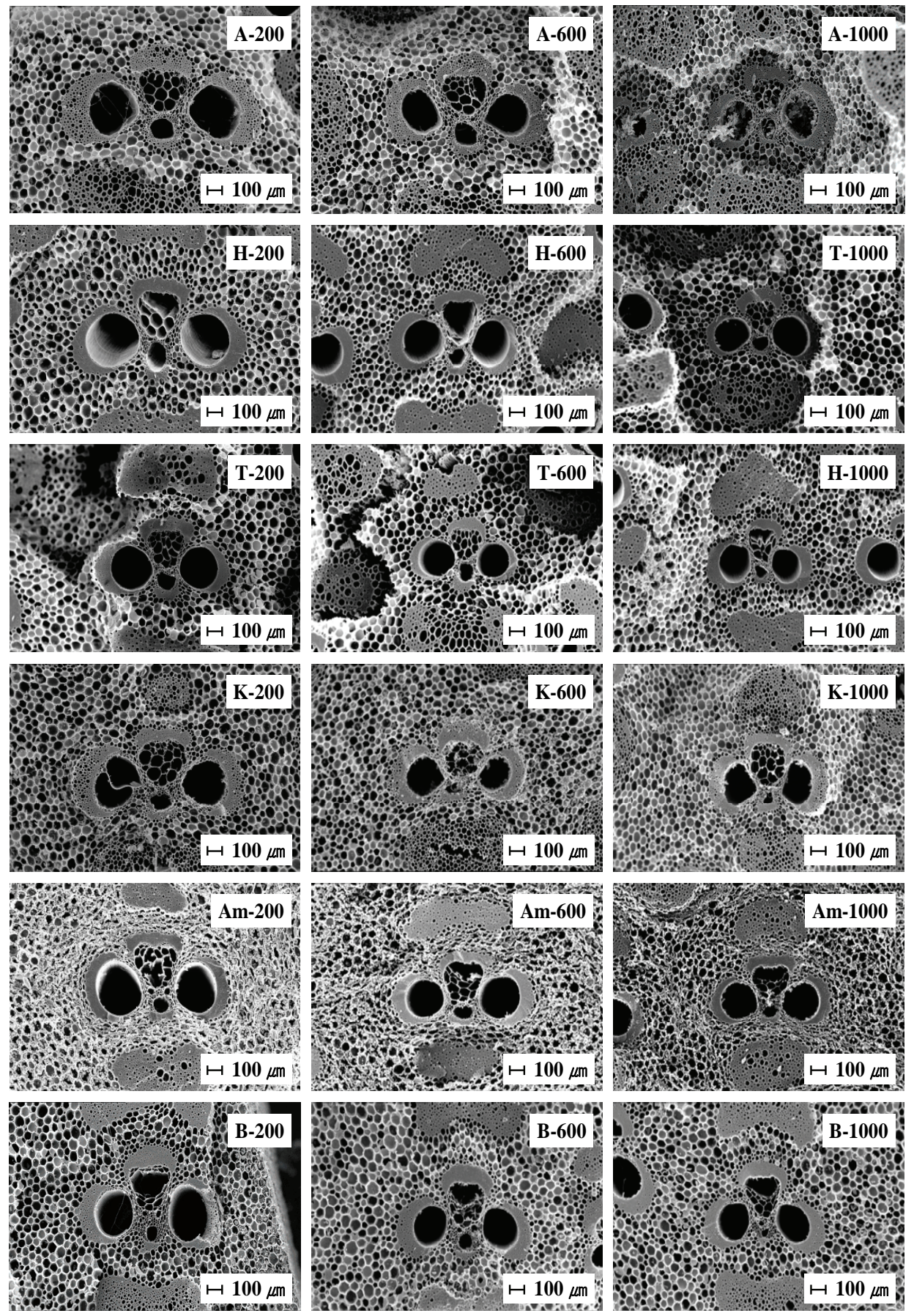

Fig. 2. SEM image on central zone of carbonized bamboo samples (A: Andong, H: Hitam, T: Tali, K: Kuning, AM: Ampel, B: Betung). 
Se-Hwi Park $\cdot$ Jae-Hyuk Jang $\cdot$ Nyoman J Wistara $\cdot$ Wahyu Hidayat $\cdot$ Min Lee $\cdot$ Fauzi Febrianto
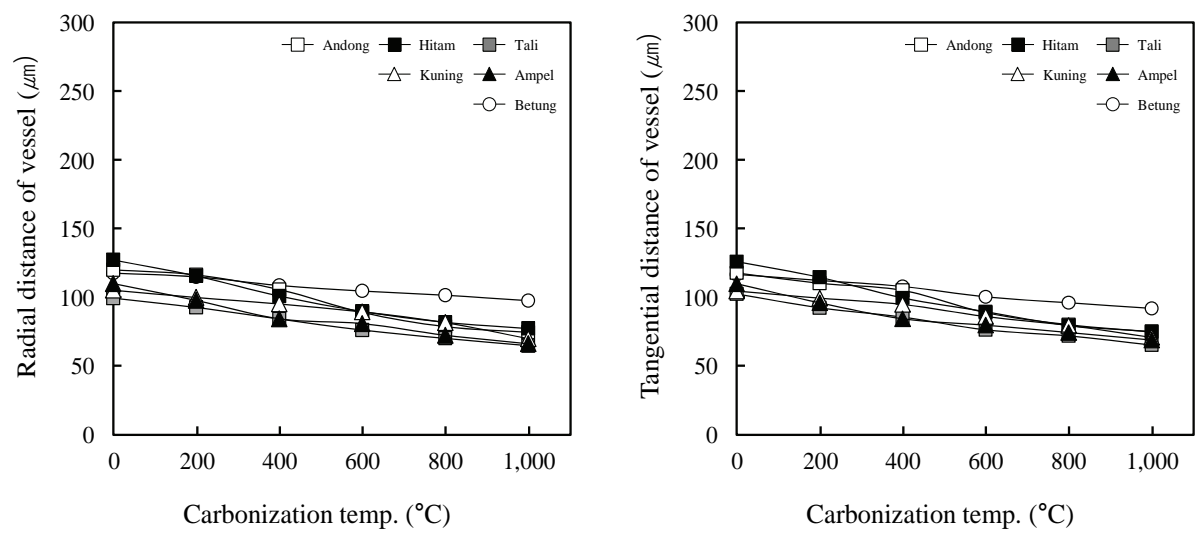

Fig. 3. Vessel diameter in transitional zone of uncarbonized and carbonized bamboo samples.
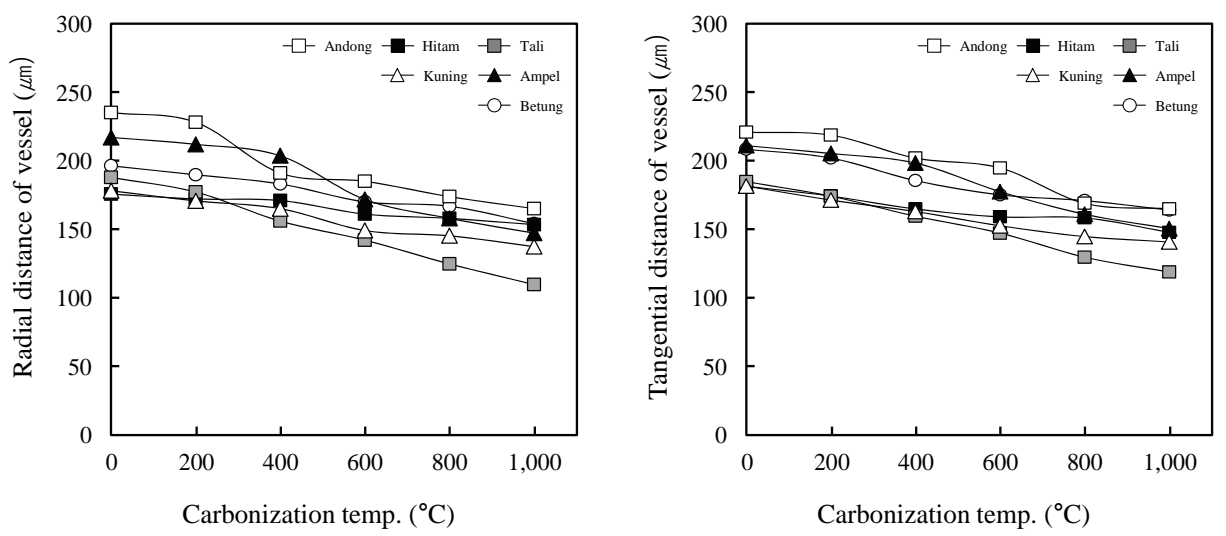

Fig. 4. Vessel diameter in central zone of uncarbonzied and carbonized bamboo samples.
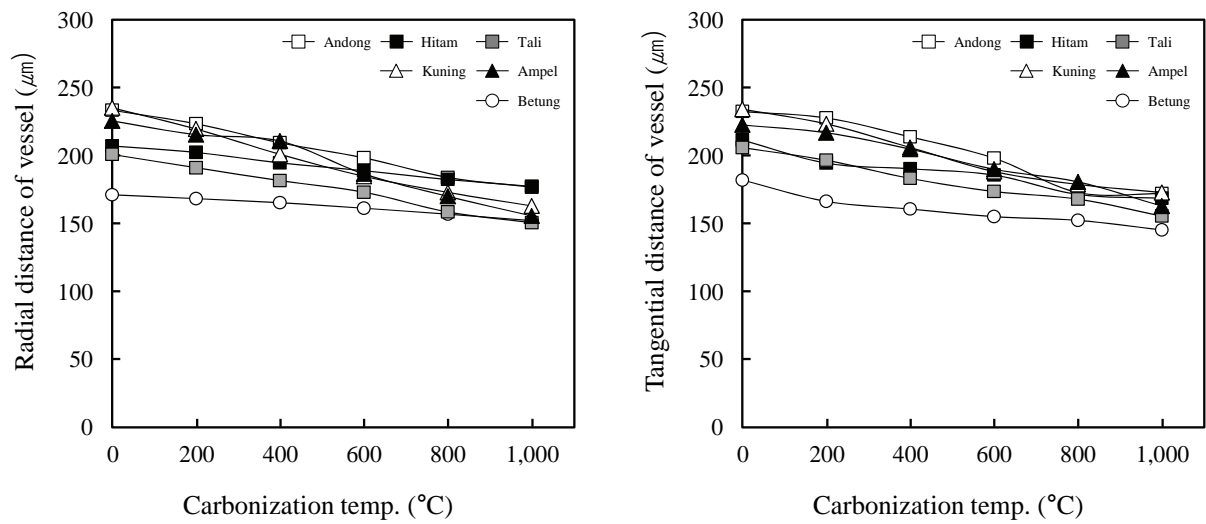

Fig. 5. Vessel diameter in inner zone of uncarbonized and carbonized bamboo samples. 
At transitional zone, the radial vessel diameters (VD) of bamboo samples were measured as 101-126 $\mu \mathrm{m}$. As increasing carbonization temperature, VD decreased until 72-100 $\mu \mathrm{m}$. The same tendency was observed in tangential direction. At $200{ }^{\circ} \mathrm{C}$, Hitam bamboo showed the highest VD. After $400{ }^{\circ} \mathrm{C}$, Betung bamboo had the highest value. Tali bamboo showed the lowest VD. Next, radial VD of uncarbonized bamboo samples in central zone were $143-233 \mu \mathrm{m}$, and there were no significant difference between radial VD and tangential VD. The VD decreased to 98-167 $\mu \mathrm{m}$. Radial VD in central zone was larger than that in transitional zone, and showed clear diameter difference between species. Among bamboo species, Andong and Kuning bamboo represented the highest and lowest VD, respectively. Finally, the radial VD in inner zone were 149-235 $\mu \mathrm{m}$ in original bamboo samples. The same trend like as previous zone was observed, and VD decreased until 100-181 $\mu \mathrm{m}$. Andong bamboo was the largest VD meanwhile, Betung bamboo showed lowest that. VD of Betung bamboo showed gentle reduction curve compared with other species. Furthermore, Betung bamboo was expected to have less cracks in carbonized product.

According to anatomical results, it was possible to directly observe the change of pore in carbonized bamboo. Generally, adsorption power of charcoal is known to be more effective for charcoal produced at 400 or $500{ }^{\circ} \mathrm{C}$ (Jiang, 2004). Although the specific surface area of bamboo charcoal increased with increasing of carbonization temperature, the physical adsorption to heavy metal having large molecular size is not sufficient due to excessive reduction of pores (Huang, et al., 2014). Abe et al. (1998) reported that charcoal produced at $600{ }^{\circ} \mathrm{C}$ had the highest adsorption ability to iodine and benzene. The charcoal produced at low temperature has been preferred in the industry of activated carbon (Park, 2007).

\subsection{Physical characteristics}

The physical properties of raw bamboo and carbonized bamboos were shown in Fig. 6, Fig. 7 and Table 3. The results showed that the weight reduction rate increased with increasing carbonization temperature. The values of weight reduction indicated 15 to $25 \%$ at $200{ }^{\circ} \mathrm{C}, 52$ to $64 \%$ at $400{ }^{\circ} \mathrm{C}, 61$ to $69 \%$ at 600 ${ }^{\circ} \mathrm{C}, 62$ to $72 \%$ at $800{ }^{\circ} \mathrm{C}$, and 64 to $75 \%$ at 1,000 ${ }^{\circ} \mathrm{C}$. Significant weight reduction was observed between carbonization temperatures of 200 to $400{ }^{\circ} \mathrm{C}$. On the other hand, there was no change between 800 and 1,000 ${ }^{\circ} \mathrm{C}$. Andong bamboo showed the lower weight reduction rate compared with other species. Basu (2013) reported that a key component of the woody material were
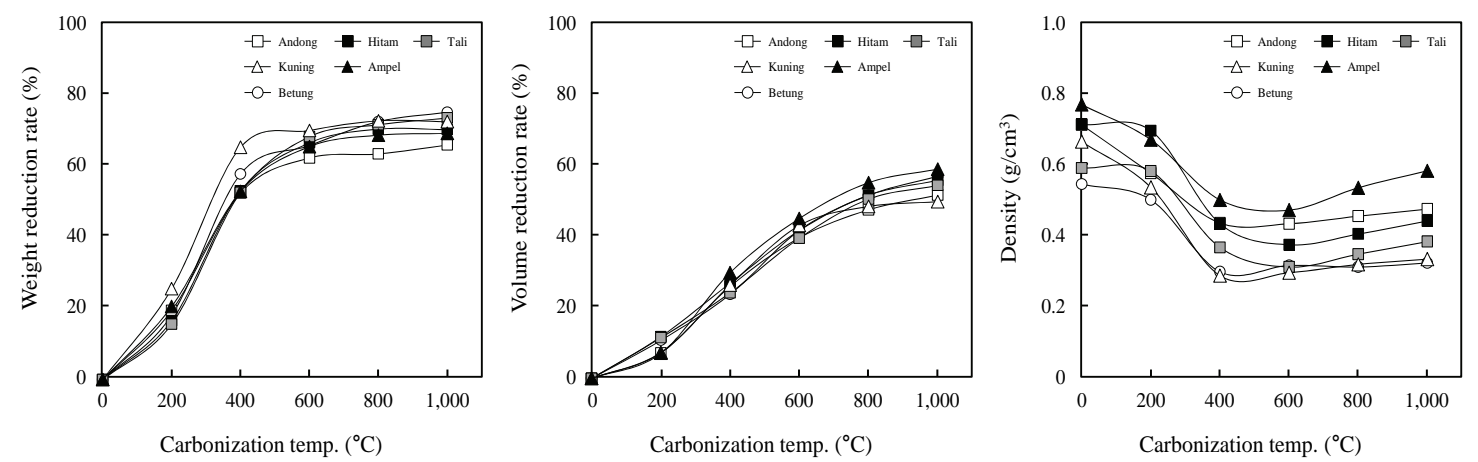

Fig. 6. Weight reduction rate, volume reduction rate, and density of uncarbonzied and carbonized bamboo samples. 
Se-Hwi Park $\cdot$ Jae-Hyuk Jang $\cdot$ Nyoman $\mathrm{J}$ Wistara $\cdot$ Wahyu Hidayat $\cdot$ Min Lee $\cdot$ Fauzi Febrianto
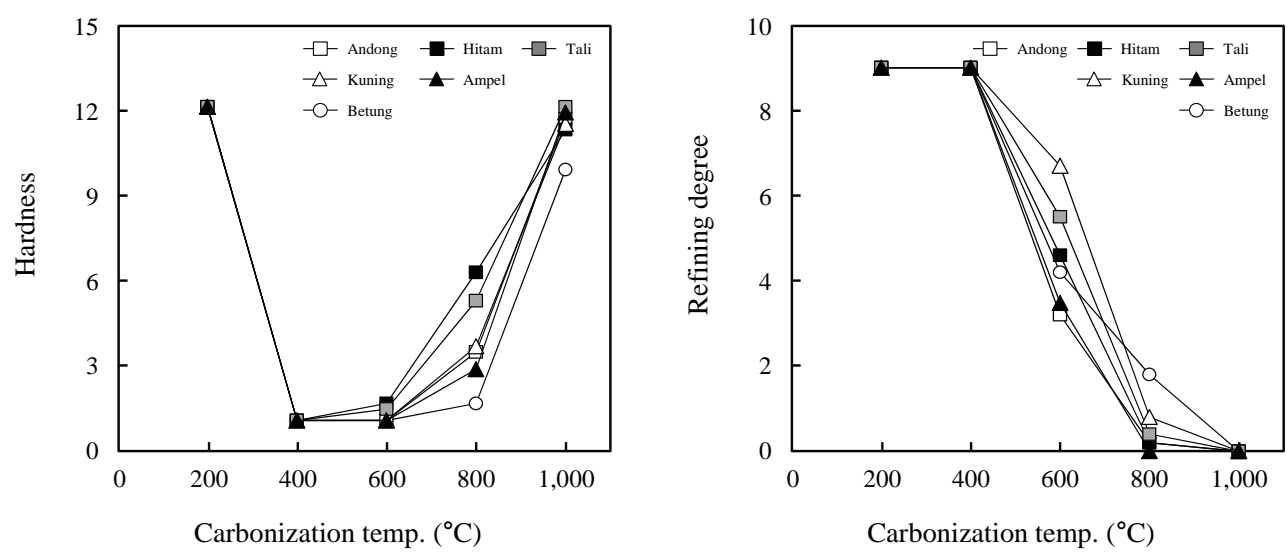

Fig. 7. Hardness and refining degree of uncarbonized and carbonized bamboo samples.

hemicellulose, cellulose and lignin, and they had different thermal decomposition behavior and degradation occurring in $225-300{ }^{\circ} \mathrm{C}, 305-375{ }^{\circ} \mathrm{C}$ and $250-500{ }^{\circ} \mathrm{C}$, respectively. Chen et al. (1985) reported that bamboo consisted of holocellulose about $70 \%$ or more of the components, and they could be easily decomposed at 200 and $400{ }^{\circ} \mathrm{C}$. Therefore, higher weight reduction ratio in this temperature range was observed in this experiment. The weight and volume reduction between the carbonization temperature of 400 and $600{ }^{\circ} \mathrm{C}$ was caused by thermal decomposition behavior of the lignin. Weight reduction below at $200{ }^{\circ} \mathrm{C}$ was mainly caused by the evaporation of water (Arias et al., 2008).

The volume reduction rate of bamboo increased as increasing carbonization temperature. Unlike the weight reduction, the volume reduction rate increased gradually and continued to increase after $600{ }^{\circ} \mathrm{C}$. This might be due to carbon component. Carbon which is the main structure of bamboo, remained without emmision of volatile matter below $600{ }^{\circ} \mathrm{C}$, and then was compressed by higher temperature (Basu, 2009). Ampel bamboo showed the highest reduction rate and Kuning showed the lowest reduction rate in this study. Kim and Hanna (2006) reported that the volume reduction rates of Quercus variablilis were about 22\%,
$29 \%, 31 \%$ and $35 \%$ at $400,600,800$ and $1,000{ }^{\circ} \mathrm{C}$, respectively. In this study, the volume reductions of bamboo specimens were significantly larger than that of wood.

The density was $0.4-0.6 \mathrm{~g} / \mathrm{cm}^{3}$ for Andong, 0.4-0.7 $\mathrm{g} / \mathrm{cm}^{3}$ for Hitam, 0.3-0.6 g/ $/ \mathrm{cm}^{3}$ for Tali, 0.3-0.6 g/ $\mathrm{cm}^{3}$ for Kuning, 0.5-0.7 g/ $/ \mathrm{cm}^{3}$ for Ampel, and 0.3-0.5 g/ $\mathrm{cm}^{3}$ for Betung. Nurhayati (1990) reported that the density of Andong, Tali, and Betung bamboos carbonized at $400{ }^{\circ} \mathrm{C}$ were $0.48 \mathrm{~g} / \mathrm{cm}^{3}, 0.40 \mathrm{~g} / \mathrm{cm}^{3}$, and $0.53 \mathrm{~g} / \mathrm{cm}^{3}$, respectively, that were similar to the results of this study. As a result of measurement of the density by carbonization temperature, it was $0.56-0.71 \mathrm{~g} / \mathrm{cm}^{3}$ at $200{ }^{\circ} \mathrm{C}, 0.32-0.51 \mathrm{~g} / \mathrm{cm}^{3}$ at $400{ }^{\circ} \mathrm{C}, 0.32-0.49 \mathrm{~g} / \mathrm{cm}^{3}$ at $600{ }^{\circ} \mathrm{C}, 0.34-0.55 \mathrm{~g} / \mathrm{cm}^{3}$ at $800{ }^{\circ} \mathrm{C}$, and $0.35-0.59$ $\mathrm{g} / \mathrm{cm}^{3}$, respectively, and decreased to $600{ }^{\circ} \mathrm{C}$, but slightly increased from $800{ }^{\circ} \mathrm{C}$. Generally, the char yield is an important factor to determine market values, and is high correlated with density of raw materials in the producing charcoal. Hidayat et al. (2017) reported that high-density wood species (A. Manigum) resulted in higher char yield compared to low-density wood.

Fig. 7 showed the results of hardness and refinement of carbonized bamboo according to carbonization temperature. As a result, the hardness showed a high 
Anatomical and Physical Properties of Indonesian Bamboos Carbonized at Different Temperatures

Table 3. Physical Properties of Uncarbonized and Carbonized Bamboo Samples

\begin{tabular}{|c|c|c|c|c|c|}
\hline $\begin{array}{c}\text { Temperature } \\
\left({ }^{\circ} \mathrm{C}\right)\end{array}$ & $\begin{array}{c}\text { Weight reduction } \\
\text { rate }(\%)\end{array}$ & $\begin{array}{c}\text { Volume reduction } \\
\text { rate }(\%)\end{array}$ & $\begin{array}{l}\text { Density } \\
\left(\mathrm{g} / \mathrm{cm}^{3}\right)\end{array}$ & Hardness & $\begin{array}{l}\text { Refining } \\
\text { degree }\end{array}$ \\
\hline \multicolumn{6}{|l|}{ Andong } \\
\hline Control & - & - & $0.71 \pm 0.02 \mathrm{De}$ & - & - \\
\hline 200 & $19.2 \pm 2.5 \mathrm{Aa}$ & $7.0 \pm 0.6 \mathrm{Aa}$ & $0.58 \pm 0.02 \mathrm{Dd}$ & $12.0 \pm 0.0 \mathrm{ABc}$ & $9.0 \pm 0.0 \mathrm{ABC}$ \\
\hline 400 & $51.9 \pm 0.3 \mathrm{Ab}$ & $25.5 \pm 4.0 \mathrm{Ab}$ & $0.45 \pm 0.05 \mathrm{Dab}$ & $1.0 \pm 0.0 \mathrm{ABa}$ & $9.0 \pm 0.0 \mathrm{ABc}$ \\
\hline 600 & $61.6 \pm 3.3 \mathrm{Ac}$ & $38.9 \pm 3.2 \mathrm{Ac}$ & $0.45 \pm 0.05 \mathrm{Da}$ & $1.0 \pm 0.0 \mathrm{ABa}$ & $3.2 \pm 0.4 \mathrm{ABb}$ \\
\hline 800 & $62.7 \pm 2.2 \mathrm{Ad}$ & $46.7 \pm 3.8 \mathrm{Ad}$ & $0.47 \pm 0.06 \mathrm{Db}$ & $3.4 \pm 0.5 \mathrm{ABb}$ & $0.2 \pm 0.4 \mathrm{ABa}$ \\
\hline 1000 & $65.2 \pm 1.9 \mathrm{Ae}$ & $50.8 \pm 1.9 \mathrm{Ae}$ & $0.49 \pm 0.05 \mathrm{Dc}$ & $11.6 \pm 0.5 \mathrm{ABc}$ & $0.0 \pm 0.0 \mathrm{ABa}$ \\
\hline \multicolumn{6}{|l|}{ Hitam } \\
\hline Control & - & - & $0.71 \pm 0.03 \mathrm{De}$ & - & - \\
\hline 200 & $16.4 \pm 0.1 \mathrm{Ba}$ & $11.5 \pm 2.3 \mathrm{Ba}$ & $0.70 \pm 0.03 \mathrm{Dd}$ & $12.0 \pm 0.0 \mathrm{Cc}$ & $9.0 \pm 0.0 \mathrm{BCc}$ \\
\hline 400 & $52.5 \pm 1.4 \mathrm{Bb}$ & $26.4 \pm 4.2 \mathrm{Bb}$ & $0.45 \pm 0.03 \mathrm{Dab}$ & $1.0 \pm 0.0 \mathrm{Ca}$ & $9.0 \pm 0.0 \mathrm{BCc}$ \\
\hline 600 & $65.8 \pm 0.1 \mathrm{Bc}$ & $41.0 \pm 0.2 \mathrm{Bc}$ & $0.40 \pm 0.02 \mathrm{Da}$ & $1.6 \pm 0.5 \mathrm{Ca}$ & $4.6 \pm 0.5 \mathrm{BCb}$ \\
\hline 800 & $69.6 \pm 0.6 \mathrm{Bd}$ & $50.8 \pm 0.5 B d$ & $0.42 \pm 0.03 \mathrm{Db}$ & $6.2 \pm 0.4 \mathrm{Cb}$ & $0.2 \pm 0.4 \mathrm{BCa}$ \\
\hline 1000 & $69.5 \pm 0.8 \mathrm{Be}$ & $54.9 \pm 1.7 \mathrm{Be}$ & $0.46 \pm 0.03 \mathrm{Dc}$ & $11.2 \pm 0.4$ Сс & $0.0 \pm 0.0 \mathrm{BCa}$ \\
\hline \multicolumn{6}{|l|}{ Tali } \\
\hline Control & - & - & $0.60 \pm 0.05 \mathrm{Ce}$ & - & - \\
\hline 200 & $15.4 \pm 0.1 \mathrm{Ba}$ & $11.2 \pm 3.3 \mathrm{ABa}$ & $0.59 \pm 0.05 \mathrm{Cd}$ & $12.0 \pm 0.0 \mathrm{Cc}$ & $9.0 \pm 0.0 \mathrm{Cc}$ \\
\hline 400 & $52.0 \pm 0.9 \mathrm{Bb}$ & $23.7 \pm 3.0 \mathrm{ABb}$ & $0.39 \pm 0.01 \mathrm{Cab}$ & $1.0 \pm 0.0 \mathrm{Ca}$ & $9.0 \pm 0.0 \mathrm{Cc}$ \\
\hline 600 & $67.6 \pm 2.4 \mathrm{Bc}$ & $38.8 \pm 0.4 \mathrm{ABc}$ & $0.34 \pm 0.01 \mathrm{Ca}$ & $1.4 \pm 0.5 \mathrm{Ca}$ & $5.5 \pm 0.5 \mathrm{Cb}$ \\
\hline 800 & $70.9 \pm 1.0 \mathrm{Bd}$ & $49.7 \pm 1.0 \mathrm{ABd}$ & $0.37 \pm 0.02 \mathrm{Cb}$ & $5.2 \pm 0.4 \mathrm{Cb}$ & $0.4 \pm 0.5 \mathrm{Ca}$ \\
\hline 1000 & $72.7 \pm 1.1 \mathrm{Be}$ & $53.5 \pm 1.3 \mathrm{ABe}$ & $0.40 \pm 0.01 \mathrm{Cc}$ & $12.0 \pm 0.0 \mathrm{Cc}$ & $0.0 \pm 0.0 \mathrm{Ca}$ \\
\hline \multicolumn{6}{|l|}{ Kuning } \\
\hline Control & - & - & $0.67 \pm 0.04 \mathrm{Be}$ & - & - \\
\hline 200 & $25.2 \pm 2.6 \mathrm{Da}$ & $7.2 \pm 1.9 \mathrm{Aa}$ & $0.55 \pm 0.03 \mathrm{Bd}$ & $12.0 \pm 0.0 \mathrm{ABc}$ & $9.0 \pm 0.0 \mathrm{Cc}$ \\
\hline 400 & $64.6 \pm 0.0 \mathrm{Db}$ & $25.9 \pm 2.9 \mathrm{Ab}$ & $0.31 \pm 0.01 \mathrm{Bab}$ & $1.0 \pm 0.0 \mathrm{ABa}$ & $9.0 \pm 0.0 \mathrm{Cc}$ \\
\hline 600 & $69.3 \pm 0.6 \mathrm{Dc}$ & $42.4 \pm 2.8 \mathrm{Ac}$ & $0.32 \pm 0.00 \mathrm{Ba}$ & $1.0 \pm 0.4 \mathrm{ABa}$ & $6.7 \pm 0.7 \mathrm{Cb}$ \\
\hline 800 & $71.9 \pm 0.4 \mathrm{Dd}$ & $47.6 \pm 2.3 \mathrm{Ad}$ & $0.34 \pm 0.01 \mathrm{Bb}$ & $3.6 \pm 0.5 \mathrm{ABb}$ & $0.8 \pm 0.4 \mathrm{Ca}$ \\
\hline 1000 & $71.7 \pm 0.6 \mathrm{De}$ & $49.0 \pm 1.7 \mathrm{Ae}$ & $0.36 \pm 0.00 \mathrm{Bc}$ & $11.4 \pm 0.5 \mathrm{ABc}$ & $0.0 \pm 0.0 \mathrm{Ca}$ \\
\hline \multicolumn{6}{|l|}{ Ampel } \\
\hline Control & - & - & $0.77 \pm 0.06 \mathrm{Ee}$ & - & - \\
\hline 200 & $20.3 \pm 0.9 \mathrm{Ba}$ & $6.9 \pm 1.4 \mathrm{Ca}$ & $0.67 \pm 0.08 \mathrm{Ed}$ & $12.0 \pm 0.0 \mathrm{Bc}$ & $9.0 \pm 0.0 \mathrm{ABC}$ \\
\hline 400 & $52.3 \pm 0.9 \mathrm{Bb}$ & $29.3 \pm 1.6 \mathrm{Cb}$ & $0.51 \pm 0.03 \mathrm{Eab}$ & $1.0 \pm 0.0 \mathrm{Ba}$ & $9.0 \pm 0.0 \mathrm{ABC}$ \\
\hline 600 & $64.8 \pm 0.2 \mathrm{Bc}$ & $44.3 \pm 1.4 \mathrm{Cc}$ & $0.49 \pm 0.04 \mathrm{Ea}$ & $1.0 \pm 0.0 \mathrm{Ba}$ & $3.5 \pm 0.4 \mathrm{ABb}$ \\
\hline 800 & $68.0 \pm 0.8 \mathrm{Bd}$ & $54.2 \pm 3.1 \mathrm{Cd}$ & $0.55 \pm 0.05 \mathrm{~Eb}$ & $2.8 \pm 0.8 \mathrm{Bb}$ & $0.0 \pm 0.0 \mathrm{ABa}$ \\
\hline 1000 & $68.4 \pm 0.9 \mathrm{Be}$ & $58.0 \pm 1.9 \mathrm{Ce}$ & $0.59 \pm 0.06 \mathrm{Ec}$ & $11.8 \pm 0.4 \mathrm{Bc}$ & $0.0 \pm 0.0 \mathrm{ABa}$ \\
\hline \multicolumn{6}{|l|}{ Betung } \\
\hline Control & - & - & $0.56 \pm 0.01 \mathrm{Ae}$ & - & - \\
\hline 200 & $17.9 \pm 0.9 \mathrm{Ca}$ & $10.5 \pm 0.9 \mathrm{Ba}$ & $0.51 \pm 0.03 \mathrm{Ad}$ & $12.0 \pm 0.0 \mathrm{Ac}$ & $9.0 \pm 0.0 \mathrm{Ac}$ \\
\hline 400 & $57.2 \pm 0.8 \mathrm{Cb}$ & $23.3 \pm 1.3 \mathrm{Bb}$ & $0.32 \pm 0.02 \mathrm{Aab}$ & $1.0 \pm 0.0 \mathrm{Aa}$ & $9.0 \pm 0.0 \mathrm{Ac}$ \\
\hline 600 & $65.1 \pm 2.1 \mathrm{Cc}$ & $41.0 \pm 0.6 \mathrm{Bc}$ & $0.34 \pm 0.04 \mathrm{Aa}$ & $1.0 \pm 0.0 \mathrm{Aa}$ & $4.2 \pm 0.5 \mathrm{Ab}$ \\
\hline 800 & $71.7 \pm 1.3 \mathrm{Cd}$ & $50.7 \pm 1.8 \mathrm{Bd}$ & $0.34 \pm 0.02 \mathrm{Ab}$ & $1.6 \pm 0.5 \mathrm{Ab}$ & $1.8 \pm 0.0 \mathrm{Aa}$ \\
\hline 1000 & $74.4 \pm 0.2 \mathrm{Ce}$ & $56.0 \pm 1.8 \mathrm{Be}$ & $0.35 \pm 0.02 \mathrm{Ac}$ & $9.8 \pm 1.3 \mathrm{Ac}$ & $0.0 \pm 0.0 \mathrm{Aa}$ \\
\hline
\end{tabular}

Notes: The means are averages of 10 measurements. Means within a column followed by the same capital letter are not significantly different between bamboo species and means within a column followed by the same lower case are not significantly different between carbonization temperature of each species at $5 \%$ significance level using Duncan's multiple range test. 
value of 12 at the carbonization temperature of $200{ }^{\circ} \mathrm{C}$. However, the hardness decreased rapidly from 1 to 2 at carbonization at 400 to $600{ }^{\circ} \mathrm{C}$, and then increased again after $800{ }^{\circ} \mathrm{C}$. Park et al. (1998) reported that the hardness of carbonized Phyllostachys pubescens and Phyllostachys bambusoides were 2 at low temperature $\left(400{ }^{\circ} \mathrm{C}\right), 5$ at medium temperature $\left(600{ }^{\circ} \mathrm{C}\right)$ and 8 at high temperature $\left(1,000{ }^{\circ} \mathrm{C}\right)$. The electric resistance between two points on the surface of carbonized material is called the refining index which is measured with a constant pressure electrode. This is an important factor in determining the degree of carbonization of char, generally 0 for white charcoal, 1 to 8 for black charcoal, lower classified as 9 (Unrinin and Yatagai, 1989). The carbonized bamboo in this study was found 9 at 200$400{ }^{\circ} \mathrm{C}$, 3-6 at $600{ }^{\circ} \mathrm{C}$, and 0 at 800-1,000 ${ }^{\circ} \mathrm{C}$. Kwon et al. (2011) showed that the degree of refinement of carbonized oak at $1,000{ }^{\circ} \mathrm{C}$ was 1 . The refining degree of bamboo was slightly lower than wood during same carbonization progress. Table 3 showed the results of the significance tests for the above analysis items, showing statistically differences in the groups classified by the bamboo type and the carbonization temperatures.

\subsection{Statistical analysis of reduction rate on whole sample and vessel element}

In order to prove this expectation and collect scientific data on anatomical experiments, the correlation between reduction rate of vessel diameter and reduction rate of whole sample was investigated. A simple regression analysis was performed to verify the statistical significance. The results are shown in Table 4 and 5. The central section of carbonized bamboo was targeted and investigated due to lower deviation.

All of the P-value (P-value) on each specimens type was lower than 0.05 and were considered statistically significant. Kim et al. (2006) suggested that the physical

Table 4. Simple Regression Analysis on Radial Reduction of Specimens (Y) and Vessel Diameter Reduction in Central Zone

\begin{tabular}{|c|c|c|c|c|c|c|}
\hline Species & $\begin{array}{c}\text { Independent } \\
\text { variable }\end{array}$ & R-squared & $\begin{array}{l}\text { Adjusted } \\
\text { R-squared }\end{array}$ & Constant & t-statistic & P-value \\
\hline \multirow{2}{*}{ Andong } & Y-intercept & \multirow{2}{*}{0.953} & \multirow{2}{*}{0.942} & -0.566 & -0.419 & $6.96 \times 10^{-1}$ \\
\hline & Vessel (X1) & & & 0.645 & 9.043 & $8.28 \times 10^{-4}$ \\
\hline \multirow{2}{*}{ Hitam } & Y-intercept & \multirow{2}{*}{0.997} & \multirow{2}{*}{0.996} & 2.392 & 5.077 & $1.47 \times 10^{-2}$ \\
\hline & Vessel (X1) & & & 1.898 & 31.138 & $7.27 \times 10^{-5}$ \\
\hline \multirow{2}{*}{ Tali } & Y-intercept & \multirow{2}{*}{0.913} & \multirow{2}{*}{0.884} & 1.222 & 0.543 & $6.24 \times 10^{-1}$ \\
\hline & Vessel (X1) & & & 0.491 & 5.609 & $1.11 \times 10^{-2}$ \\
\hline \multirow{2}{*}{ Kuning } & Y-intercept & \multirow{2}{*}{0.951} & \multirow{2}{*}{0.939} & -0.421 & -0.288 & $7.87 \times 10^{-1}$ \\
\hline & Vessel (X1) & & & 0.977 & 8.823 & $9.10 \times 10^{-5}$ \\
\hline \multirow{2}{*}{ Ampel } & Y-intercept & \multirow{2}{*}{0.907} & \multirow{2}{*}{0.876} & 4.769 & 1.688 & $1.89 \times 10^{-1}$ \\
\hline & Vessel (X1) & & & 0.763 & 5.418 & $1.23 \times 10^{-2}$ \\
\hline \multirow{2}{*}{ Betung } & Y-intercept & \multirow{2}{*}{0.964} & \multirow{2}{*}{0.951} & -0.212 & -0.107 & $9.21 \times 10^{-1}$ \\
\hline & Vessel (X1) & & & 1.381 & 8.904 & $2.98 \times 10^{-3}$ \\
\hline
\end{tabular}


Table 5. Simple Regression Analysis on Tangential Redcution of Specimens (Y) and Vessel Diameter Reduction in Central Zone

\begin{tabular}{|c|c|c|c|c|c|c|}
\hline Species & $\begin{array}{l}\text { Independent } \\
\text { variable }\end{array}$ & R-squared & $\begin{array}{l}\text { Adjusted } \\
\text { R-squared }\end{array}$ & Constant & t-statistic & P-value \\
\hline \multirow{2}{*}{ Andong } & Y-intercept & \multirow{2}{*}{0.902} & \multirow{2}{*}{0.869} & 5.852 & 2.613 & $7.94 \times 10^{-2}$ \\
\hline & Vessel (X1) & & & 0.724 & 5.253 & $1.34 \times 10^{-2}$ \\
\hline \multirow{2}{*}{ Hitam } & Y-intercept & \multirow{2}{*}{0.910} & \multirow{2}{*}{0.879} & -1.004 & -0.313 & $7.75 \times 10^{-1}$ \\
\hline & Vessel (X1) & & & 1.491 & 5.491 & $1.18 \times 10^{-2}$ \\
\hline \multirow{2}{*}{ Tali } & Y-intercept & \multirow{2}{*}{0.986} & \multirow{2}{*}{0.991} & 1.073 & 1.001 & $3.90 \times 10^{-1}$ \\
\hline & Vessel (X1) & & & 0.679 & 14.413 & $7.24 \times 10^{-4}$ \\
\hline \multirow{2}{*}{ Kuning } & Y-intercept & \multirow{2}{*}{0.981} & \multirow{2}{*}{0.988} & -0.699 & -0.805 & $4.79 \times 10^{-1}$ \\
\hline & Vessel (X1) & & & 1.016 & 18.204 & $3.61 \times 10^{-5}$ \\
\hline \multirow{2}{*}{ Ampel } & Y-intercept & \multirow{2}{*}{0.918} & \multirow{2}{*}{0.967} & 5.861 & 2.348 & $1.00 \times 10^{-1}$ \\
\hline & Vessel (X1) & & & 0.814 & 5.785 & $1.02 \times 10^{-2}$ \\
\hline \multirow{2}{*}{ Betung } & Y-intercept & \multirow{2}{*}{0.973} & \multirow{2}{*}{0.964} & 1.479 & 0.864 & $4.50 \times 10^{-1}$ \\
\hline & Vessel (X1) & & & 1.206 & 10.373 & $1.91 \times 10^{-3}$ \\
\hline
\end{tabular}

properties of woody material were generally related to the structure and observing the structure of charcoal according to the carbonization temperature would be important in assessing the quality of charcoal. Vessel element of carbonized bamboo measured in this study could be utilized as anatomical indicators related to part of physical properties.

\section{CONCLUSION}

Based on the results of physical and anatomical characteristics of Indonesian bamboo carbonized at various temperatures, we can conclude that:

1. The volume and weight of carbonized bamboo decreased with increasing carbonization temperature and showed the greatest change between 200 and $400{ }^{\circ} \mathrm{C}$. Kuning and Ampel bamboo showed highest weight reduction and weight reduction, respectively.

2. The density of carbonized bamboo decreased until $600{ }^{\circ} \mathrm{C}$ and then increased slightly until $1,000{ }^{\circ} \mathrm{C}$. Density was the highest in Ampel bamboo and the lowest in Betung bamboo.

3. According to result of hardness and refining degree test, carbonized bamboo of all species seemed to be good carbonization quality when manufactured above $800{ }^{\circ} \mathrm{C}$.

4. It was confirmed that the arrangement of the vascular bundles was different depending on the position of bamboo structure in cross section. Unlike other bamboo species, the type III of vascular bundle was frequently observed in Andong bamboo.

5. As the results of measuring vessel diameter, it was found that the difference between radial direction and tangential direction of all species was not significant. The reduction tendency of 
vessel diameter on Betung bamboo was different with other species.

6. Correlations between reduction of whole-sample and reduction of vessel were considered to be statistically significant. Therefore, it was considered that vessel element could be used as antomical indicators related to part of physical properties.

\section{REFERENCES}

Abe, I., Iwasaki, S., Iwata, Y., Kominami, H., Kera, Y. 1998. Relationship between production method and adsorption property of charcoal. TANSO 185: 277-284.

Arias, B., Pevida, C., Fermoso, J., Plaza, M.G., Rubiera, F., Pis, J.J. 2008. Influence of torrefaction on the grindability and reacitivity of woody biomass. Fuel Processing Technology 89: 169-175.

Basu, P. 2013. Biomass gasfication, pyrolysis and torrefaction: practical design and theory. Academic press. San Diego, USA.

Chen, Y., Qin, W., Li, X., Gonianping, N. 1985. The chemical composition of ten bamboo species. In: Recent Research on Bamboos, 110, Ed. by Rao, A.N., Dhanarajan, G., Sastry, C.B., The chinese Academy of Forestry, People's Republic of China and International Development Research Centre, Otawa, Canada.

Febrianto, F., Jang, J.H., Lee, S.H., Santosa, I.A., Wahyu, H., Kwon, J.H., Kim, N.H. 2015. Effect of bamboo species and resin content on properties of oriented strand board prepared from steamtreated bamboo strands. Bioresources 10(2): 26422655.

Febrianto, F., Gumilang, A., Maulana, S., Busyra, I., Purwantiningsih, A. 2014. Natural durability of five bamboo species against termite and powder post beetle. Journal of Tropical Wood Science and Technology 12(2): 146-156.

Febrianto, F., Sahroni, Hidayat, W., Bakar, E.S., Kwon,
G.J., Kwon, J.H., Kim, N.H. 2012. Properties of oriented strand board made from betung bamboo (Dendrocalamus asper (Schultes.f) Backer ex Heyne). Wood Science and Technology 46: 53-62.

Grosser, D., Liese, W. 1971. On the anatomy of Asian bamboo, with special reference to their vascular bundles. Wood Science and Technology 5: 290-312.

Hardiani, N., Dewy, K.K. 2014. Indonesian bamboo national strategy. In: 2014 Indonesia Invites second edition, 17. Ed. by Wihanasari, T., Ministry of Foreign Affatirs of the Republic of Indonesia, Jakarta, Indonesia.

Hidayat, W., Qi, Y., Jang, J.H., Febrianto, F. 2017. Carbonization characteristics of juvenile woods from some tropical trees planted in Indonesia. Journal of the Faculty of Agriculture, Kyushu University 62(1): 145-152.

Huang, P.H., Jhan, J.W., Cheng, Y.M., Cheng, H.H. 2014. Effects of carbonization parameters of Moso-bamboo-based porous charcoal on capturing carbon dioxide. The Scientific World Journal 2014: 1-8.

Hyodo, K., Fujii, Y. 2016. Consideration about quality evaluation of charcoal as fuel. Forest research, Kyoto 79: 43-53.

International Networ for Bamboo and Rattan (INBAR). 2005. Global forest resources assessment 2005, 8, INBAR's Assessment. International Network for Bamboo and Rattan, Working paper, Rome, Italy. Jang., J.H., Lee, S.H., Febrianto, F., Endo, T., Kim, N.H. 2013. Manufacturing nano-cellulose composite of Betung bamboo treated by delignification. Proc. of 2013 Annual Meeting of The Korean Society of Wood Science and Technology, pp. 102-103. Jeon, W.S., Byeon, H.S., Kim, N.H. 2018. Anatomical characteristics of Korean Phyllostachys pubescens by age. Journal of the Korean Wood Science and Technology 46(3): 231-240.

Jiang, S. 2004. Training manual of bamboo charcoal for producers and consumers. Bamboo Engineering 
Research Center, Nanjing Forestry University, Nanjing, China.

Kim, N.H., Hanna, R.B. 2006. Morphological characteristics of Quercus variabilis charcoal prepared at different temperatures. Wood Science and Technology 40: 392-401.

Kim, Y.J., Jung, K.H., Park S.J., Roh, J.K. 2001. A morphological comparison of bamboo zephyr produced from phyllostachys nigra var. henonis and Indonesian Gigantochloa apus. Journal of the Korean Wood Science and Technology 29(2): 84-90.

Kim, N.H., Hwang, W.J., Kwon, S.M., Kwon, G.J., Lee, S.J. 2006. Anatomy of Quercus variabilis charcoal manufactured at various temperatures. Journal of the Korean Wood Science and Technology 34(4): 1-8.

KSA. 2016. KS F 2198: Determination of density and specific gravity of wood. Korean Standards Association.

KSA. 2016. KS F 2199: Determination of moisture content of wood. Korean Standards Association.

Kwon, G.J., Kwon, S.M., Jang, J.H., Hwang, W.J., Kim, N.H. 2011. Charcoal properties and temperature change of a kiln's inner and outer walls in carbonization process using an improved kiln. Journal of the Korean Wood Science and Technology 39(3): 230-237.

Liese, W. 1987. Research on bamboo. Wood Science and Technology 21: 189-209.

Lobovikov, M., Ball, L., Guardia, M., Russo, L. 2007. World bamboo resources: a thematic study prepared in the framework of the global forest resources assessment 2005. Viale delle Terme di Caracalla, Rome, Italy.

Maulana, S., Busyra, I., Fatrawana, A.. Hidayat, W., Sari, R.K., Sumardi, I., Wistara, I.N.J., Lee, S.H., Kim, N.H, Febrianto, F. 2017. Effects of steam treatment on physical and mechanical properties of bamboo oriented strand board. Journal of the
Korean Wood Science and Technology 45(6): 872882.

Mizuta, K., Matsumoto, T., Hatate, Y., Nishihara, K., Nakanishi, T. 2004. Removal of nitrate-nitrogen from drinking water using bamboo powder charcoal. Bioresource Technology 95: 255-257.

Nurhayati, T. 1990. Charcoal manufacture test of 4 bamboo species by pit method. Journal of Forest Product Research 6(8): 500-503.

Park, S.B., Kwon, S.D., Ahn, K.D., Cha, S.H. 1998. Characterization of bamboo charcoal( I ). Proc. of 1998 Annual Meeting of The Korean Society of Wood Science and Technology, pp. 266-271.

Park, S.B. 2007. Research material of National Institute of Forest Science: Bamboo - Bamboo Charcoal · Bamboo Vinegar. National Institute of Forest Science. Seoul, Korea.

Park, S.B., Lee, S.M., Park, J.Y., Lee, S.H. 2009. Manufacture of crack-free carbonized baord from fiberboard. Journal of the Korean Wood Science and Technology 37(4): 293-299.

Sutardi, S.R., Nadjib, N., Jansi, M.M., Sulastiningsih, I.M., Komaryati, S., Suprapti, S., Abdurrahman, Basri, E. 2015. Informasi sifat dasar dan kemungkinan penggunaan 10 jenis bambu. IPB Press, Bogor, Indonesia.

Unrinin, G., Yatagai, M. 1989. Development of movable charcoal making kilns. Japan Agricultural Research Quarterly 23(2): 144-150.

Wang, F.W., Wang, H., Ma, J.W. 2010. Adsorption of cadmium( II ) ions from aqueous solution by a new low-cost adsorbent - Bamboo charcoal. Journal of Hazardous Materials 177: 300-306.

Yudodibroto, H. 1985. Bamboo research in Indonesia. In: Recent Research on Bamboos, 33, Ed. by Rao, A.N., Dhanarajan, G., Sastry, C.B., The chinese Academy of Forestry, People's Republic of China and International Development Research Centre, Otawa, Canada. 